\title{
The Influence of Demographic and Herbal Characteristics on Purchase Decisions of Zingiberacea Familia: An Exploration in Kota Bharu, Kelantan Society
}

\author{
Nurulwahidah Fauzi, Rubayah Yakob
}

\begin{abstract}
In Malaysia, for over a decade a product of Zingibereacea familia especially ginger are coming as one of the famous product in Malaysian market. The study brings out green product from Zingiber Officianale Roscoe (Ginger) among 100 respondents in Kota Bharu, Kelantan with a primary objective to search a response from the customer's either this product can be presumed to be environmentally safe should be preserved as a medicinal plant and commercialized within and outside the country. In regard to the fact that "Green Marketing" is developed as a products that are presumed to be environmentally safe. The objective of this research was to determine usage profiles and some variables that influence the purchase decision of herbal medicine in Kota Bharu Kelantan, and (2) to evaluate the consumer's response on the development of Zingiberacea Familia Based Product, either it can be a symbol of herbs that can be lifted as a health and beauty product in the preservation and preservation of Malay culture. Primary data was collected from the survey tabulated within the Kota Bharu society, and secondary data was collected from the available literature sources. The core idea of the finding are a world view is also a two-way bridge: A respondent shows a positive reaction that Zingibearacea Familia product could be be a symbol of herbs that can be lifted as a health and beauty product in the preservation and preservation of Malay culture. On the other hand, only age characteristic showed significant influence on purchase decision of green product from Zingiberacea Familia, on the other hand races, level of education and job sector didn't show positive influence
\end{abstract}

Index Terms: Influence, Demographic, Green product, Zingiberacea familia, Kota Bharu.

\section{INTRODUCTION}

During ancient times, natural ingredients were the main ingredients in cosmetic and health products. The term Green marketing came into prominence in the late 1980s and early 1990s. Green marketing is growing rapidly, and consumers are willing to pay a lot for green product. There has been little analysis of the impact of this new market on the consumers and the environment so far. According to Kamboj (2000),

Revised Manuscript Received on September 22, 2019.

Nurulwahidah Fauzi, Senior Lecturer, Faculty of Quranic and Sunnah Studies, Universiti Sains Islam Malaysia, 71800, Bandar Baru Nilai, Negeri Sembilan, MALAYSIA, wahidah@usim.edu.my

Rubayah Yakob, Associate Professor, Finance and Risk Management \& Financial Services Programme, Faculty of Economics and Management, Universiti Kebangsaan Malaysia, 43650 Bandar Baru Bangi, Selangor, MALAYSIA, rubayah@ukm.edu.my. herbal medicine is still being used by $75-80 \%$ of world population, mainly in developing countries for primary health care because of better cultural acceptability, better compatibility with the human body and lesser side effects [1]. Based on the World Health Organization (WHO) information, in present, $80 \%$ of the world's populations still dependent on medicinal plants, at once giving a big hope that traditional herbal medicine research will play a critical role in global health [2].

In Malaysian perspectives, G. Rezai in his research has quoted that in $2009,69.4 \%$ of our society have used traditional and complementary medicine (TCAM) at least once in their life time. Furthermore, 55.6\% of those surveyed have used it in the previous 12- month period [3], with the consumer background are those of villagers compared to the cities. Its reflect by the factors on the biggest population of herbs are mostly found in villages.

Among variety of herbs exist in Malaysian market, Zingiberacea Familia are one of the herbs species that boomed as a popular product nowadays, either in health or ornamentals, condiments and spices. These species are used in treatment for various diseases for the previous generation and existed as a prescription in treating tropical diseases or ailments, including post-partum protective treatment, cures for diarrhea, stomach-aches, indigestion, rheumatism, fever, coughs, asthma, swellings and vermifuge. They are also used in the making of jamu, herbal medicines, nutrient supplements and other specific purposes. Beside the popularity of the product from these type of herbs, not very much information is known about the influences associated with the expenditure for purchase decision of the product and reaction of the consumer's toward Zingiberacea Familia. There are several research have identified factors associated with herbal spending, on the other hand there have been several studies using the theory of planned behavior to investigate the use of herbal medicine. From the background which has been described, the objective of this study was to determine the profile and the influence of

demographic characteristics on the purchase decision and a response from consumer's towards the development of

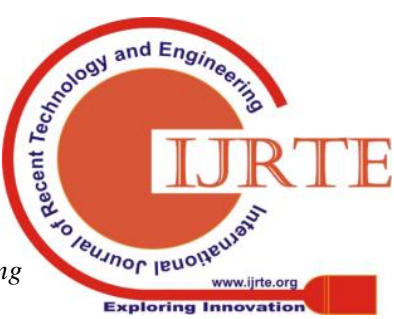


green product from Zingiberacea Familia.

Based on the theory presented hypotheses can be drawn as follows:

- H1: Age characteristic influence purchase decisions of green product from Zingiberacea Familia.

- H2: Races characteristic influence purchase decisions of green product from Zingibearcea Familia.

- H3: Level of Education characteristic influence purchase decisions of green product from Zingiberacea Familia.

- H4: Job Sector characteristic influence purchase decisions of green product from Zingiberacea Familia.

- H5: Understanding the product affect a positive reaction toward Zingiberacea Familia marketing.

\section{MATERIAL AND METHODS}

A total of six species of Zingiberaceae family herbs, which were studied are, ginger, turmeric, galangal, greater galangal and bitter ginger, study about the awareness of local people on herbal medicine products and cosmetics industry.

A questionnaire was developed in the Malay language based on information collected from a literature search, in-depth interviews conducted with consumers prior to this study and consultations with experts. Data type is a primary data sources which is collected as the first-hand by the researcher for a specific research project in regard to analyze the Customer's Attitude and Awareness towards Green Product with Reference to Zingiberacea Familia: An Analytical Study to Kota Bharu, Kelantan Society. There were 20 questions on the questionnaire, which were divided into four parts as follows: (a) Demographic background, (b) understanding, (c) effect on the Zingiberacea product consumes, (d) consumer's response towards Zingiberacea product development. The demographic background section consisted of 6 questions, and the rest of the sections consisted of 6,4 and 4 , respectively. The possible responses to the questionnaires comprised (1) "yes, no and do not know" for the understanding section and (2) a four-point Likert scale for all sections. A final version of the questionnaire was piloted among 30 consumers via convenient sampling. A descriptive analysis was performed, and the internal consistency and the differences between variables in the questionnaire were analyzed. Test-retest reliability was used to determine the consistency of the test in a period of time. The questionnaire was distributed to 30 people, and a Spearman rank correlation analysis was used to determine the consistency of the questionnaire. The final version of questionnaire was tabulate within 130 respondent within Kota Bharu, Kelantan in regard of the consumer's consumption the majority of product's related to Zingibearcea familia are concentered to this area.

The data collected from the respondents are tabulated and analyzed into logical statements using percentage and mean score analysis. Secondary data was collected from the available literature, journals and web search.

\section{DATA COLLECTION}

A cross-sectional study design was employed to assess consumers' awareness, perceptions, and attitudes toward cosmetic products. This pilot test was conducted in Kota Bharu area area, as the state city of Kelantan in regard of the consumer's consumption the majority of product's related to Zingibearcea familia are concentered to this area. Public places in this district, such as educational institutions, community pharmacies, and community halls were selected to perform this study.

The participants for this pilot test were selected via convenient sampling based on the following criteria: (1) Aged between 18 and 45 years old and above, (2) current user of the cosmetic product(s), and (3) an ability to understand the benefits and importance of herbs from Zingiberacea Familia. People in the selected areas were approached by the researcher, and the study was explained to them. Interested consumers were asked to answer all of the questions in the questionnaire. On average, the participants were able to complete the questionnaire within 10-15 min.

\section{RESULT}

The data collected in this study were tabulated and analyzed Statistical Package for the Social Sciences (SPSS) version 22. Before the data was analyzed, there were steps to be followed as suggested by Hair, Black, Babin, and Anderson [4] and Tabachnick and Fidell [5], that is, check each data accurately entered, handle incomplete data, and run data normality tests to handle outliers. Data scanning process at the initial stage was carried out, such as a total of 100 data was encoded and included in the SPSS program and cleaned first before being analyzed. In this study, all questionnaires are complete and free from offenses.

\section{Reliability Statistics}

\begin{tabular}{ll}
\hline Cronbach's Alpha & N of Items \\
\hline .841 & 4 \\
\hline
\end{tabular}

The developed and translated questionnaire produced repeatable data for each of the domains (Spearman's correlation $\geq 0.7, \mathrm{P}<0.001)$. The internal consistency for the consumer response towards herbs product from Zingiberacea familia indicates good internal consistency (Cronbach's alpha value of more than 0.7 for each domain).

Result shows that only age characteristic showed significant influence on purchase decision of green product from Zingiberacea Familia, on the other hand races, level of education and job sector didn't show positive reaction.

\section{DATA ANALYSIS AND INTERPRETATION}

\section{A. Demographic Characteristics}

Table 1: Descriptive analysis on demographic respondent

\begin{tabular}{ll} 
Variable Category & $\begin{array}{l}\text { Percentag } \\
\text { e \% }\end{array}$ \\
\hline
\end{tabular}


Gender

Male

Female

39.0

61.0

\begin{tabular}{|c|c|c|}
\hline Age & $18-24$ years & 28.0 \\
\hline & 25-34 years & 29.0 \\
\hline & $35-44$ years & 28.0 \\
\hline & $>45$ years & 15.0 \\
\hline Race & Malay & 92.0 \\
\hline & Chinese & 06.0 \\
\hline & Indian & 01.0 \\
\hline & Diploma/Certificate & 14.0 \\
\hline Education level & Bach. Degree & 34.0 \\
\hline & Master & 4.0 \\
\hline & $\mathrm{PhD}$ & 2.0 \\
\hline & Others & 46.0 \\
\hline & $<$ RM500 & 33.0 \\
\hline & RM501-RM1500 & 28.0 \\
\hline Monthly Income & RM1501-RM3000 & 26.0 \\
\hline & RM3001-RM5000 & 11.0 \\
\hline & RM5001 > & 02.0 \\
\hline Employment Status & Public worker & 18.0 \\
\hline & $\begin{array}{l}\text { Private sector } \\
\text { employee }\end{array}$ & 07.0 \\
\hline & Self-employed & 22.0 \\
\hline & Student & 24.0 \\
\hline & Housewife & 25.0 \\
\hline & Others & 0.4 \\
\hline
\end{tabular}

The results of the in the table (1) above data analysis clearly show that the average respondents consist of those aged between 18 years old and up to 45 years old and above. The result of the data analysis also showed that the findings were dominated by women respondents which are $61 \%$ compared to male respondents, which is $39 \%$. Based from the ethnic groups that found in Malaysia, the largest number of respondents was from the ethnic group of Malays with 92\%, followed by ethnic Chinese at $6.0 \%$, same with Chinese, respondent from ethnic Indian also $1.0 \%$ and the last is from other ethnic groups which amounted to $1.0 \%$. Most of the respondents in this study were those aged 18-24 who account for $28 \%$, and followed up to those aged 25-34 years of $29 \%$, while $28 \%$ for those aged 35-44 and the latter are those aged 45 and above which is $15 \%$.

From the analysis, it was found that the highest respondent income rate was RM500 and below, accounting for 33\% followed by a revenue of RM501 to RM1500 of 28\%, then by RM1501-3000 income of $26 \%$ and for income RM3001-5000 there are $11 \%$ and the last which is RM5001 and above is $2 \%$.

The results of the education level analysis showed that respondents who received the highest level of education were $34 \%$ degree followed by respondents who had diploma level education with $14 \%$, while for master level $4 \%$ and finally for $\mathrm{PhD}$ level 2\%. While for the others, such as SPM or STAM/STPM scored the highest response with the total respondent is $46 \%$. The descriptive data related to the respondent's job are as follows; public workers is $18 \%$, private sector is $7 \%$, self employed is $22 \%$ of respondent, students is $24 \%$. While for the highest respondents are among students with $25 \%$, and the last one is other occupation with $4 \%$.

\section{DISCUSSION}

\section{A. Descriptive Data of Consumer Effect on The Usage of Zingiberaceae's Based Products}

Table 2: Consumer Effect on The Usage of Zingiberaceae's Based Products

\begin{tabular}{|c|c|c|}
\hline Variable & Category & Percentage \% \\
\hline Product & D'Herbs & 91.0 \\
\hline \multirow[t]{2}{*}{ Usage } & Jus Tok Guru & 01.0 \\
\hline & Yusmira & 08.0 \\
\hline \multirow{2}{*}{$\begin{array}{l}\text { Herb's } \\
\text { Understanding } \\
\text { (Zingibearcea) }\end{array}$} & Yes & 38.0 \\
\hline & No & 61.0 \\
\hline \multirow{3}{*}{$\begin{array}{l}\text { Product } \\
\text { Satisfaction }\end{array}$} & Good Effect & 95.0 \\
\hline & Not Good Effect & 01.0 \\
\hline & Not Applicable & 04.0 \\
\hline \multirow[t]{5}{*}{ Product Effect } & Burns fat and calory & 97.0 \\
\hline & Reduce bloating and gas & 01.0 \\
\hline & Ease digestion & 01.0 \\
\hline & $\begin{array}{l}\text { Cleansing and tighten } \\
\text { skin }\end{array}$ & 01.0 \\
\hline & Advertisement & 81.0 \\
\hline \multirow{3}{*}{$\begin{array}{l}\text { Motivation On } \\
\text { product Usage }\end{array}$} & Friends & 7.0 \\
\hline & Social Media & 5.0 \\
\hline & Reading & 7.0 \\
\hline
\end{tabular}

Based on the result showed in Table 2, there is a positive response on the usage on Zingiberacea Familia product even though the percentage of product understanding within consumer are only $38 \%$. It might be related to the factors of advertisement that showing the high percentage of $81 \%$. Based on the result by Svetlana Frolova [6], she has reported that the concept of advertising effectiveness contains such different ideas as economic benefits, psychological and social effect expressed in a certain impact on the society in whole (in particular, the influence on the formation of taste preferences of people, their views and ideas about different moral and material values). Beside the effective advertisement as the main factors of purchase behavioral within consumer's, the positive result of product usage are playing a big role in promoting the purchasing of Zingibearcea Familia product as well. The result in table 2 above shows that there is a positive response within the usage in help the consumer in burning their fat and calories while using the product.

Table 3: Consumer response result on the development of Zingiberacea Familia Based Product

\section{Min Max Mean Std.}


The Influence of Demographic and Herbal Characteristics on Purchase Decisions of Zingiberacea Familia: An Exploration in Kota Bharu, Kelantan Society

Do you agree with the

statements below? Ginger can

be a symbol of herbs that can

be lifted as a health and beauty $2.00 \quad 4.00 \quad 3.7500 \quad .45782$

product in the preservation and

preservation of Malay culture.

Ginger should be preserved as

a medicinal plant and

commercialized within and

$\begin{array}{llll}3.00 & 4.00 & 3.6900 & .46482\end{array}$

outside the country.

Is the study of herbs based on

Zingiberaceae family as

intellectual property rights in

cosmetics products in the

market?

Do you think that ginger

should be lifted into herbal

komedi to generate the

country's economy from

aspect and beauty?

Based from descriptive data (Table 3), 60\% of respondent agree that Zingiberacea familia should be raised into herbal commodities to generate the country's economy from aspect health and beauty, while $29 \%$ of them very agree with the statement, followed with $9 \%$ that disagree with it and lastly, $2 \%$ very disagree to raise ginger as a herbal commodity to generate the country's economy in terms of beauty and beauty. Next, $57 \%$ of respondent agree to put ginger as a symbol of herbs that can be raised as a health and beauty product in the preservation and preservation of Malay culture. Then, $32 \%$ very agree with that statement, followed with $10 \%$ which is disagree with it and the least is $1 \%$ which is very disagree to put ginger as a symbol of herbs that can be raised as a health and beauty product in the preservation and preservation of Malay culture. On the hand, for Ginger should be preserved as a medicinal plant and commercialized within and outside the country, $56 \%$ of respondent agree and $32 \%$ are very agree with it. Total of disagree is $11 \%$ and for very disagree with that statement only $1 \%$. Lastly, there are $55 \%$ of respondents agree about research on herbs as intellectual property rights in cosmetic products in the market needs to be enhanced, $35 \%$ very agree with it. Total of disagree is $9 \%$ and for very disagree is $1 \%$.

There are (4) variable item that has been used to measure each item in measuring the consumer's respond, which are min, max, mean and standard deviation. All of the table below shows the average value as a whole to respond users of herbal products from Zingiberacea Familia;

\section{B. Consumer respond analysis verses gender, age, level of education and job sector}

\section{1) Response Vs Gender}

Value $p=0.519>\alpha=0.05$ then this indicates that the response to herbal products is not different between men and women. In other words, gender does not influence the response to herbal products.
2) Response Vs Ages

\begin{tabular}{llllll}
\hline & $\begin{array}{l}\text { Sum of } \\
\text { Squares }\end{array}$ & df & $\begin{array}{l}\text { Mean } \\
\text { Square }\end{array}$ & F & Sig. \\
\hline $\begin{array}{l}\text { Between } \\
\text { Groups }\end{array}$ & 1.138 & 3 & .379 & 2.572 & .059 \\
$\begin{array}{l}\text { Within } \\
\text { Groups }\end{array}$ & 14.160 & 96 & .147 & & \\
Total & 15.298 & 99 & & & \\
\hline
\end{tabular}

3) 3. Response Vs Races

\begin{tabular}{lccccc}
\hline & $\begin{array}{l}\text { Sum of } \\
\text { Squares }\end{array}$ & df & $\begin{array}{l}\text { Mean } \\
\text { Square }\end{array}$ & F & Sig. \\
\hline Between & .376 & 3 & .125 & .806 & .494 \\
$\begin{array}{l}\text { Groups } \\
\text { Within }\end{array}$ & 14.922 & 96 & .155 & & \\
$\begin{array}{l}\text { Groups } \\
\text { Total }\end{array}$ & 15.298 & 99 & & & \\
\hline
\end{tabular}

4) 4. Response Vs Level of Education

\begin{tabular}{lcccccc}
\hline & $\begin{array}{l}\text { Sum of } \\
\text { Squares }\end{array}$ & df & \multicolumn{2}{c}{$\begin{array}{l}\text { Mean } \\
\text { Square }\end{array}$} & F & \multicolumn{1}{c}{ Sig. } \\
\hline $\begin{array}{l}\text { Between } \\
\text { Groups }\end{array}$ & .190 & 4 & .048 & .299 & .878 \\
$\begin{array}{l}\text { Within } \\
\text { Groups }\end{array}$ & 15.107 & 95 & .159 & & \\
Total & 15.298 & 99 & & & \\
\hline
\end{tabular}

5) 5. Response Vs Job's Sector

\begin{tabular}{|c|c|c|c|c|c|}
\hline & $\begin{array}{l}\text { Sum of } \\
\text { Squares }\end{array}$ & df & $\begin{array}{l}\text { Mean } \\
\text { Square }\end{array}$ & $\mathbf{F}$ & Sig. \\
\hline Between & 1.224 & 5 & .245 & 1.635 & .158 \\
\hline Groups & & & & & \\
\hline Within & 14.074 & 94 & .150 & & \\
\hline Groups & & & & & \\
\hline Total & 15.298 & 99 & & & \\
\hline
\end{tabular}

Based on analysis of no 2 to 5 only age found significant at the level of significance $\alpha=0.1$ ( $p=0.059)$ with respond to the herbal products. This means that respond to the herbal products are found to vary across age. Post-hoc test results confirm that only age category 18-24 and 45 who have respond to the herbal products that differ significantly at the significance level $\alpha=0.1 \quad(p=0.064)$. While the characteristics of respondents who include race, education level and occupation did not affects response to herbal products.

For the whole, some important result can be conclude as;

i. The consumer's react in the positive way regarding the benefits of Zingiberacea Familia herb's product, even though without in-depth understanding on the usage of the plants. It might cause with an experience possess of the consumption of medicinal plants by the previous generation in local health management. Thus, the result shows a significance of response of consumer's are vary within age.

ii. The consumer's also agree that Zingiberacea familia should be raised into herbal commodities to generate the country's economy from aspect health and beauty, and as a symbol

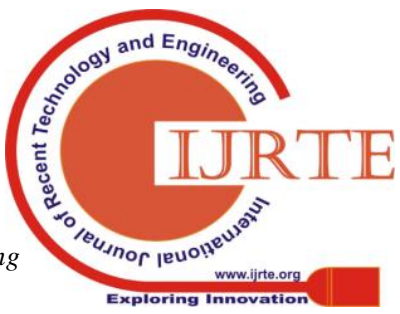


of herbs that can be raised as a health and beauty product in the preservation and preservation of Malay culture.

iii. More over, consumer's shows a positive reaction that research on herbs as intellectual property rights in cosmetic products in the market needs to be enhanced.

\section{CONCLUSION}

From the result, it can be seen that consumers of green product from Zingiberacea shows a significant influence with the age characteristics within a community in Kota Bharu Kelantan. Medicinal plants especially from Zingiberacea Familia could contribute significantly to market target as it showing a positive response from consumer's. This review strongly recommends the importance of proper and comprehensive documentation of the traditional healing methods to be promoted as in might help for sustainable development for the medicinal plants in Malaysia in general.

\section{REFERENCES}

[1] Kamboj, V. P. (2000). Herbal medicine. Current Science, 78(1), 35-51.

[2] Jon C Tilburt, Ted J Kaptchuk (2008 ). Herbal Medicine Research and Global Health:An Ethical Analysis in Bulletin of The World Health Organization, Vol 86(8), 577-656.

[3] G. Rezai, Z. Mohamed, M. N. Shamsudin and M. Z. Zahran (2013). "Effect of Consumer Demographic Factors on Purchasing Herbal Products Online in Malaysia", in World Academy of Science, Engineering and Technology International Journal of Economics and Management Engineering 7(8), 2013, pp. 2380-2385

[4] Joseph F. Hair Jr, et.al (2014). Multivariate Data Analysis. Essex: Pearson Eduaction Limited.

[5] Tabachnick, B. G., \& Fidell, L. S. (2007). Using Multivariate Statistics (5th ed.). New York: Allyn and Bacon.

[6] Svetlana Frolova (2014). The Role of Advertising in Promoting Product. Thesis Centria University Of Applied Sciences Degree Programme in Industrial Management, pp 47-48.

\section{AUTHORS PROFIL}

I am Nurulwahidah Fauzi, currently working as a Senior Lecturer, Faculty of Quranic and Sunnah Studies, Universiti Sains Islam Malaysia, and my area of interest is Social Behavior's. for any query contact me at 71800, Bandar Baru Nilai, Negeri Sembilan, MALAYSIA, wahidah@usim.edu.my

My name is Rubayah Yakob, currently affiliated as an Associate Professor, Finance and Risk Management \& Financial Services Programme, Faculty of Economics and Management, Universiti Kebangsaan Malaysia, my area of interest is Risk Management and my postal address is 43650 Bandar Baru Bangi, Selangor, MALAYSIA, rubayah@ukm.edu.my . 